\title{
Algae and Bioguano as promising source of organic fertilizers
}

\author{
Giulia Atzori ${ }^{1}$ - Werther Guidi Nissim ${ }^{1} \cdot$ Liliana Rodolfi $^{1,2}$ (I) $\cdot$ Alberto Niccolai $^{1} \cdot$ Natascia Biondi $^{1} \cdot$ Stefano Mancuso $^{1}$. \\ Mario R. Tredici ${ }^{1}$
}

Received: 28 March 2020 / Revised and accepted: 14 September 2020 / Published online: 29 October 2020

(C) The Author(s) 2020

\begin{abstract}
The projected population growth implies an increased food demand with a severe impact on Earth's natural resources. Improving crops yield without compromising the environment will be one of the main challenges of the next decades. Among the practices that can promote sustainable agriculture, organic fertilizers, and seaweeds in particular, are receiving growing attention. The aim of the current study was to test two macroalgae (Chaetomorpha sp. and Cystoseira sp.), one microalga (Chlorella $\mathrm{CH} 2$ ) and Bioguano (a mixture of macroalgae, spirulina, and guano) as organic fertilizers for the growth of barley seedlings. Remarkable plant growth was obtained on Bioguano, with seedlings showing a comparable total biomass yield with respect to the positive control plants on mineral fertilizer. Plants growth on macroalgae was reduced, even if in Chaetomorpha sp. not significantly compared to the positive control. Plants growth on Chlorella $\mathrm{CH} 2$ was close to that of the negative control (only water). Plants on Bioguano attained high uptake efficiencies of $\mathrm{N}$ $(60 \%)$ and K (41\%). Plants on macroalgae showed high N, and especially P (about 30\%) uptake efficiency. Our results suggest a high potential for Bioguano and, to a lesser extent, for macroalgae without any synthetic fertilizer application to be used as growing substrates for crops.
\end{abstract}

Keywords Biofertilizers $\cdot$ Chlorophyta $\cdot$ Phaeophyta $\cdot$ Chaetomorpha $\cdot$ Cystoseira $\cdot$ Chlorella $\cdot$ Bioguano $\cdot$ Barley

\section{Introduction}

Projected population growth will lead to an increase in the global food demand in the next years (Calicioglu et al. 2019). Such increase, along with the climate change effects, will have a severe impact on the Earth's natural resources (FAO 2017). Agriculture, among the main users of natural resources, is already responsible for about $25 \%$ of greenhouse gas emissions, the use of synthetic fertilizers being one of the main causes (FAO 2016, 2017). Chemical fertilizers allowed a doubling in food production after their massive introduction with the Green Revolution, increasing the global per capita food availability, reducing hunger and improving nutrition (Tilman et al. 2002). In fact, more than a

Liliana Rodolfi

liliana.rodolfi@unifi.it

1 Department of Agriculture, Food, Environment and Forestry (DAGRI), University of Florence, Piazzale delle Cascine 18, 50144 Florence, Italy

2 Fotosintetica \& Microbiologica S.r.1., Via di Santo Spirito 14, 50125 Florence, Italy quarter of the world population over the past century is estimated to have been fed by synthetic nitrogen fertilizers (Ramankutty et al. 2018). Nevertheless, fertilizers have severe detrimental impacts on the environment, with on top of all the degradation of water quality (Foley et al. 2005; Ramankutty et al. 2018). In comparison with 2010, application of $\mathrm{N}, \mathrm{P}_{2} \mathrm{O}_{5}$, and $\mathrm{K}_{2} \mathrm{O}$ fertilizers will have to be increased by up to $70 \%, 50 \%$, and $300 \%$, respectively, to attain the potential yields (Pradhan et al. 2015). The challenge of increasing food production is directly associated with the need of not further deteriorating the soil and water resources which are already under great stress. Accordingly, improving crop yield without compromising the environment will be one of the main challenges of the next decades (Chaudhari et al. 2018). The use of organic fertilizers is among the practices that can promote sustainable agriculture and are generally considered environmental friendly and cost-effective (Garcia-Gonzalez and Sommerfeld 2016). Such practice focuses on the recycling of organic residues from a number of natural sources and human activities (Senesi 1989). The most common organic fertilizers are classified as follows: (i) organic $\mathrm{N}$-fertilizers (with at least $5 \% \mathrm{~N}$ ); (ii) organic P-fertilizers (with at least $25 \% \mathrm{P}_{2} \mathrm{O}_{5}$ ); (iii) organic NP-fertilizers (with at least $3 \% \mathrm{~N}$ and $12 \%$ 
$\mathrm{P}_{2} \mathrm{O}_{5}$ ); (iv) organic NPK-fertilizers (with at least $15 \% \mathrm{~N}$, $\mathrm{P}_{2} \mathrm{O}_{5}$, and $\mathrm{K}_{2} \mathrm{O}$ together); (v) organo-mineral NP- or NPKfertilizers, supplemented by mineral fertilizer or guano ${ }^{1}$ (NP with at least $5 \%$ each of $\mathrm{N}$ and $\mathrm{P}_{2} \mathrm{O}_{5}$, or NPK with at least $4 \%$ each of $\mathrm{N}, \mathrm{P}_{2} \mathrm{O}_{5}$, and $\mathrm{K}_{2} \mathrm{O}$ ) (FAO 2006). In addition to these, different types of organic sources that are receiving growing attention are seaweeds (macroalgae), which have been used for centuries as a source of nutrients for plants and biostimulants (du Jardin 2015; Lötze and Hoffman 2016).

With the general term algae, we refer to a wide group including the macroscopic, multicellular marine algae (macroalgae), and the microscopic species (microalgae). Commercially manufactured extracts of a variety of seaweeds have been used extensively for several decades for the relief of abiotic and biotic stresses in agricultural crops and horticulture, to improve yield and quality (Hurtado and Critchley 2018). In fact, several beneficial effects have been documented for plants grown with seaweeds or seaweed extracts, including early seed germination, improvement of crop performances and yield, increased resistance to biotic and abiotic stresses, better root development, increased nutrient uptake and better plant tissue composition (Stirk et al. 2020), increased plant height, number of leaves per plant, total leaves area per plant, fresh and dry weight of shoot, significant increase of chlorophyll $a$ and $b$ and total chlorophyll, increase in nitrogen, phosphorus and potassium content, as well as total sugar and total amino acid concentrations (Zodape 2001; Khan et al. 2009; Sayed et al. 2018; Stirk et al. 2020). The general assumption is that hormones native to the seaweeds maintain their activity in the manufactured extracts (Craigie 2011). The positive effects of extracts on plant growth were proved to be related not only to the macro and micronutrient content but also to amino acids, vitamins, cytokinins, auxins, and abscisic acid (ABA)-like growth substances, which are responsible for the enhanced crop growth and yield (Stirk et al. 2020). The current commercial products are mainly obtained from the brown seaweeds Ascophyllum nodosum, Laminaria/Saccharina spp., Ecklonia maxima, Sargassum spp., and Durvillaea spp., even though, to a lesser extent, also microalgae are used as manure and soil conditioning agents (Craigie 2011; Salvi et al. 2019).

Microalgae can be particularly attractive as they present high biomass productivity, they can be produced on marginal lands and on salt water, they do not require herbicides or pesticides, and they can synthesize high-value co-products (Tredici 2010; Win et al. 2018). When considering microalgae, and particularly those of the genus Chlorella, Chlorella vulgaris was reported to increase nutrients uptake, chlorophyll synthesis, shoot, and root

\footnotetext{
${ }^{1}$ The term guano indicates a special group of organic fertilizers derived from the excreta of small animals. It represents an important source of nutrients for plant growth already used by farmers in many regions, with an $\mathrm{N}$ content ranging from 0.4 to $9 \%$ and total $\mathrm{P}_{2} \mathrm{O}_{5}$ of $12-26 \%$ (FAO 2006).
}

growth in maize (Shaaban 2001). Chlorella fusca increased growth of both spinach and Chinese chives, as well as leaf number and mineral content increase in spinach and a reduction of gray mold disease in Chinese chives (Kim et al. 2018). Extracts from C. vulgaris increased germination of sugar beet seeds (Puglisi et al. 2020). Extracts from different Chlorella species were able to increase root and shoot length as well as chlorophyll content in leaves and, only some of the extracts tested, N, P, and $\mathrm{K}$ root content, root, and shoot dry weight and carotenoid leaf content in 40-day-old tomato plants (Chanda et al. 2020). Such positive results, obtained testing algae as biofertilizers, soil additives, and/or biostimulants, encourage the testing of more algal species, as availability of organic fertilizers from only few sources might in time become inadequate (Zodape 2001).

The aim of the current study was to test two macroalgae (Chaetomorpha sp. and Cystoseira sp.), one microalga (Chlorella $\mathrm{CH} 2$ ) and Bioguano, a commercial product composed of guano, macroalgae, and spirulina (Arthrospira platensis), as organic fertilizers for the growth of barley seedlings.

\section{Materials and methods}

\section{Experimental design and plant material}

The trial was carried out in a growth chamber under the following environmental conditions: air temperature $30 / 22{ }^{\circ} \mathrm{C}$ day/night, relative humidity $65 \%$, light intensity $500 \mu \mathrm{mol}$ photons $\mathrm{m}^{-2} \mathrm{~s}^{-1}$, light duration $12 \mathrm{~h}$. Six plastic containers $(35 \times 22 \times 15 \mathrm{~cm})$ were used to grow barley (Hordeum vulgare L.) hydroponically, in the number of 24 seedlings per container. Each container will be referred to as "system." Barley was chosen because of its rapid vegetative growth and quick response to nutrient supply (e.g., nitrogen) compared to other cereals (Delogu et al. 1998). Selected commercial barley seeds var. "Meseta" were obtained from SemEtica Srl. Seeds were first germinated in a dark chamber for 4 days at $25{ }^{\circ} \mathrm{C}$ and then transferred in a perforated polystyrene sheet to support the plants in the hydroponic system. At the beginning of the experiment, all the substrates were placed into dialysis membranes (Medicell International Ltd, Dialysis TubingVisking Size 9, MWCO-12-14000 Da) to prevent any possible physical obstruction of plant roots and each container was filled up to a total volume of $3 \mathrm{~L}$ of tap water, which were maintained during the experiment, and continuously aerated throughout the trial.

\section{Substrate characterization and dosage}

Six different growing media were obtained by mixing tap water and one of the following substrates: 
1 Cystoseira sp., a brown alga of the order Fucales, collected from the Laguna di Orbetello, Italy, rinsed with demineralized water, immediately frozen and stored at $-20{ }^{\circ} \mathrm{C}$ until use for the experiment.

2 Chaetomorpha sp., a green alga of the order Cladophorales, collected from the Laguna di Orbetello, Italy, rinsed with demineralized water, immediately frozen and stored at $-20^{\circ} \mathrm{C}$ until use for the experiment.

3 Chlorella $\mathrm{CH} 2$, a strain of the order Chlorellales, cultivated outdoors in a GWP photobioreactor (Tredici et al. 2016) in F medium (Guillard and Ryther 1962), biomass harvested, lyophilized, ground, and stored at $-20^{\circ} \mathrm{C}$ until use for the experiment.

4 Bioguano, a dried powder made of guano (75\%), macroalgae (22\%) and Arthrospira platensis (3\%), obtained from Algafuels S.A. Technology Consortium (Santiago, Chile).

In addition, two controls were set up:

5 Positive control (Control +): 1/4 strength Hoagland solution (Hoagland 1938).

6 Negative control (Control -): tap water only.

The substrates were handled as follows:

Substrates 1, 2, and 3: defrosted and added with tap water Substrate 4: added with tap water

The elemental composition of the substrates is reported in Table 1.

The amount of substrate supplied to each system was chosen on the basis of its nitrogen content and rate of release through the dialysis membrane. The positive control conditions for barley seedlings growth were individuated as onefourth Hoagland solution according to several authors (Barber and Koonts 1963; Zhao et al. 2015; He et al. 2019). The full recipe includes the following salts: $\mathrm{KNO}_{3}, \mathrm{Ca}\left(\mathrm{NO}_{3}\right)_{2} \cdot 4 \mathrm{H}_{2} \mathrm{O}$, Fe-Na EDTA, $\mathrm{MgSO}_{4} \cdot 7 \mathrm{H}_{2} \mathrm{O}, \mathrm{H}_{3} \mathrm{BO}_{3}, \mathrm{MnCl}_{2} \cdot 4 \mathrm{H}_{2} \mathrm{O}$, $\mathrm{ZnSO}_{4} .7 \mathrm{H}_{2} \mathrm{O}, \mathrm{CuSO}_{4} .5 \mathrm{H}_{2} \mathrm{O}, \mathrm{H}_{2} \mathrm{MoO}_{4} \cdot \mathrm{H}_{2} \mathrm{O}$, $\mathrm{Na}_{2} \mathrm{MoO}_{4} \cdot 2 \mathrm{H}_{2} \mathrm{O}, \mathrm{KH}_{2} \mathrm{PO}_{4}$, at $1 / 4$ strength of the following concentrations: N 210 ppm, K 235 ppm, Ca 200 ppm, P 31 ppm, S 64 ppm, Cl 0.65 ppm, Na 1.2 ppm, Mg 48.6 ppm, B

Table 1 Elemental composition of the substrates (\% of dry weight)

\begin{tabular}{llllllll}
\hline Treatment & $\begin{array}{l}\mathrm{N} \\
\%\end{array}$ & $\begin{array}{l}\mathrm{P} \\
\%\end{array}$ & $\begin{array}{l}\mathrm{K} \\
\%\end{array}$ & $\begin{array}{l}\mathrm{Fe} \\
\%\end{array}$ & $\begin{array}{l}\mathrm{Mg} \\
\%\end{array}$ & $\begin{array}{l}\mathrm{Ca} \\
\%\end{array}$ & $\begin{array}{l}\mathrm{Na} \\
\%\end{array}$ \\
\hline Cystoseira sp. & 2.76 & 0.25 & 3.32 & 0.63 & 0.64 & 2.40 & 2.19 \\
Chaetomorpha sp. & 3.15 & 0.15 & 4.24 & 0.29 & 0.48 & 1.77 & 1.75 \\
Chlorella $\mathrm{CH} 2$ & 7.94 & 1.10 & 0.92 & 0.11 & 0.46 & 0.46 & 1.14 \\
Bioguano & 1.75 & 1.65 & 1.44 & 0.49 & 0.60 & 4.08 & 1.46 \\
\hline
\end{tabular}

0.5 ppm, Fe 2.9 ppm, Mn 0.5 ppm, Zn 0.05 ppm, Cu 0.02 ppm, Mo 0.05 ppm.

Tests on $\mathrm{N}$ release through the dialysis membrane were conducted on Cystoseira sp. (70\% of $\mathrm{N}$ released), Chaetomorpha sp. (50\% of $\mathrm{N}$ released), and Chlorella $\mathrm{CH} 2$ (20\% of $\mathrm{N}$ released), whereas the Bioguano dosage was determined considering its $\mathrm{N}$ content as fully available. Total $\mathrm{N}$ was determined in the substrate and in the medium outside the dialysis membrane (Spectroquant, VWR Italia, Italy). The value in the medium (released N) was divided by the value in the substrate and the ratio was used to calculate the amount of substrate to add in each treatment to ensure uniform conditions of $\mathrm{N}$ availability for plant growth. The substrates were supplied as follows (expressed in grams of dry weight per system): Cystoseira sp., $10.8 \mathrm{~g}$; Chaetomorpha sp., $12.8 \mathrm{~g}$; Chlorella CH2, $12.8 \mathrm{~g}$; Bioguano, $13.2 \mathrm{~g}$. The amount of nutrients supplied per system is reported in Table 2 .

\section{Plant sampling and growth analyses}

At the beginning of the trial (T0), 24 plantlets per system were fresh weighed before being placed in the polystyrene sheet. Afterwards, plants biomass was determined through destructive harvests performed on a weekly basis: T1 one week $(n=4)$, T2 two weeks $(n=6)$, T3 three weeks $(n=6)$, T4 four weeks $(n=6)$. Sampled plants were divided into shoots and roots and weighed separately. All roots samples were rinsed with demineralized water and then oven-dried at $70{ }^{\circ} \mathrm{C}$ until constant weight. Also, leaf samples were oven-dried $\left(70{ }^{\circ} \mathrm{C}\right.$ until constant weight) and dry biomass was determined on both root and leaf samples (T1 $n=4$; T2T4 $n=6$ ). Plant mortality was recorded at the end of the trial. Dry weight at T0 was calculated based on the fresh weight measured for the 24 plants multiplied by the dry weight/ fresh weight ratio of the plants at $\mathrm{T} 1$.

\section{Elements determination in the plant}

Elemental composition was determined on $0.1 \mathrm{~g}$ of oven-dried ground barley samples (all the plants pooled) collected at the end of the experiment (T4) and mineralized in Teflon vessels in CEM microwave Mars Xpress with $10 \mathrm{~mL}$ of $\mathrm{HNO}_{3}$. The microwave settings were power $1600 \mathrm{~W}$ applied at $100 \%$, ramp of 15:00 min to reach $200{ }^{\circ} \mathrm{C}$, and held for 15:00 min. At the end of this process, the final volume of the solution was obtained by adding $25 \mathrm{~mL}$ of water $18 \mathrm{M} \Omega$ and diluted extracts were analyzed for $\mathrm{N}$ content according to the Dumas method, using an EA (Elemental Analyzer Flash EA 1112) Thermo Fisher Scientific (USA) (ISO 2016; Krotz et al. 2016). Diluted extracts were also used for $\mathrm{P}, \mathrm{K}, \mathrm{Fe}, \mathrm{Mg}, \mathrm{Ca}$, and $\mathrm{Na}$ content determination by means of ICP OES (Inductively Coupled Plasma-Optical Emission 
Table 2 Elements supplied per system

\begin{tabular}{|c|c|c|c|c|c|c|c|}
\hline Treatment & $\begin{array}{l}\mathrm{N} \\
\mathrm{mg}\end{array}$ & $\begin{array}{l}\mathrm{P} \\
\mathrm{mg}\end{array}$ & $\begin{array}{l}\mathrm{K} \\
\mathrm{mg}\end{array}$ & $\begin{array}{l}\mathrm{Fe} \\
\mathrm{mg}\end{array}$ & $\begin{array}{l}\mathrm{Mg} \\
\mathrm{mg}\end{array}$ & $\begin{array}{l}\mathrm{Ca} \\
\mathrm{mg}\end{array}$ & $\begin{array}{l}\mathrm{Na} \\
\mathrm{mg}\end{array}$ \\
\hline Control + & 157.50 & 23.25 & 176.25 & 2.17 & 36.45 & 150.00 & n.a. \\
\hline Cystoseira sp. & 298.08 & 27.06 & 358.45 & 68.32 & 69.07 & 259.09 & 236.95 \\
\hline Chaetomorpha sp. & 402.90 & 18.78 & 542.26 & 37.57 & 61.43 & 225.93 & 224.40 \\
\hline Chlorella $\mathrm{CH} 2$ & 1015.83 & 140.53 & 117.31 & 14.49 & 58.48 & 58.76 & 146.03 \\
\hline Bioguano & 231.00 & 218.41 & 190.23 & 64.03 & 78.52 & 538.03 & 192.98 \\
\hline
\end{tabular}

n.a., not available

Spectrometer) Thermo Fisher Iris Intrepid II, based on Atomic Emission Spectroscopy, according to the EPA method (EPA 1996), modified as in Guidi Nissim et al. (2019). The element contents were then multiplied by the total dry weight of plants (summing the dry weights of the 22 plants recorded when harvested: $n=4$ at T1, $n=6$ at T2, T3, and T4).

\section{Element uptake efficiency}

Element uptake efficiency was calculated by multiplying the plant element content at $\mathrm{T} 4$ by the weight of all harvested plants per system (at T1, T2, T3, and T4), then dividing by the amount of each element provided in each system, as for nitrogen in Le Gouis et al. (2000).

\section{Nitrogen use efficiency}

Nitrogen use efficiency (NUE) was calculated according to the following formula:

$\mathrm{NUE}=\mathrm{DW}_{\text {plants }} / N_{\text {subs }}$

where $\mathrm{DW}_{\text {plants }}$ is the dry weight of all plants produced in each system throughout the experiment (mg), and $N_{\text {subs }}$ are the $\mathrm{mg}$ of nitrogen provided with each substrate, as in Le Gouis et al. (2000).
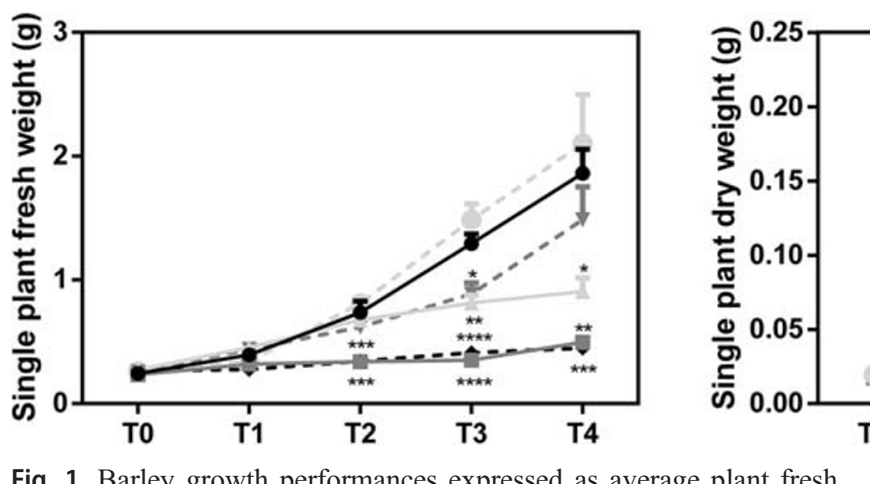

Fig. 1 Barley growth performances expressed as average plant fresh weight $(\mathrm{g})$ (left), and average plant dry weight (g) (right). Values are means \pm SEM (T0, $n=24$; T1, $n=4$; T2-T4, $n=6$ ). Significant

\section{Statistical analyses}

One-way ANOVA test followed by Tukey's test was used to assess significant differences among treatments. The significance level was $P \leq 0.05$. Statistical analyses were conducted using GraphPad Prism 5 for Windows.

\section{Results}

\section{Plant growth response}

The evolution of biomass yield in barley plantlets from $\mathrm{T} 0$ to $\mathrm{T} 4$, expressed as average plant fresh (FW) and dry (DW) weight, respectively, is reported in Fig. 1.

Considering both FW and DW, differences among treatments appeared two weeks after the start of the experiment, with the biomass produced in the negative control and with Chlorella $\mathrm{CH} 2$ significantly lower compared to the positive control until the end of the trial. Regarding the other substrates, remarkable biomass growth was obtained with Bioguano, which led to a higher, even if not statistically significant, yield than the positive control. Chaetomorpha sp. substrate gave a lower yield although not significantly different from the positive control, whereas Cystoseira sp. substrate at 
Fig. 2 Barley shoot performances expressed as average plant dry weight $(\mathrm{g})$. Values are means \pm SEM (T1, $n=4$; T2-T4, $n=6$ ). Significant differences compared to the positive control $(\mathrm{Control}+)$ are indicated as follows: $* P<$ $0.05 ; * * P<0.01 ; * * * P<0.001$ (Tukey's test, $P<0.05$ )

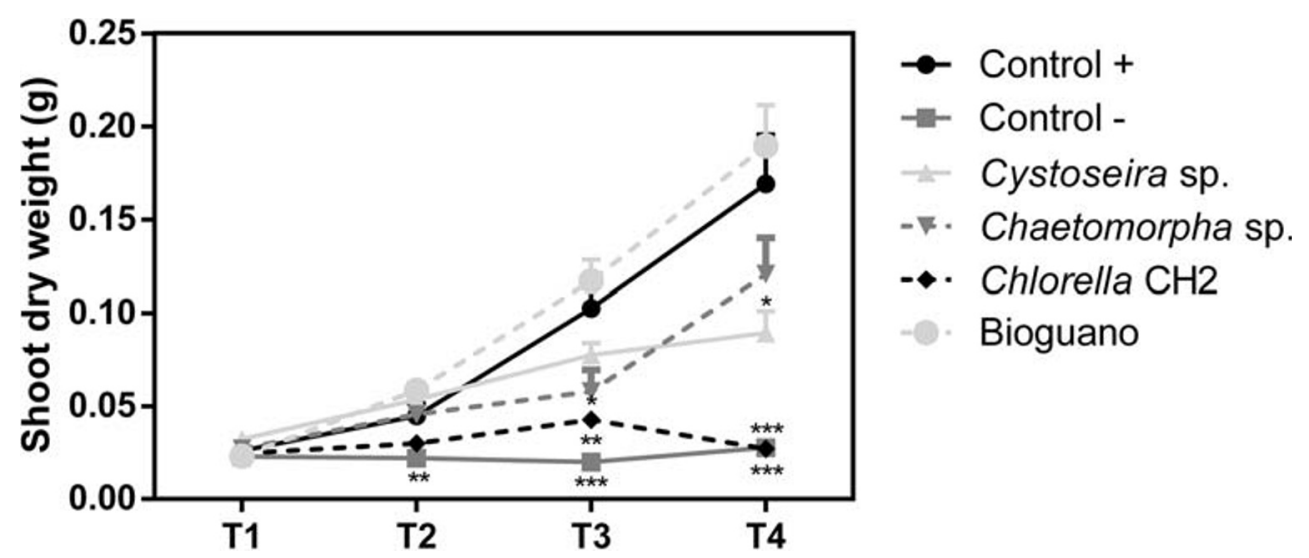

T4 resulted in a significantly lower biomass production compared to the positive control.

In Fig. 2 the shoot dry weight of plants is reported. Significant differences between the positive and negative control in shoot dry biomass occurred from T2 until the end of the trial. Shoots grown with Chlorella $\mathrm{CH} 2$ were reduced compared to the positive control at $\mathrm{T} 3$ and $\mathrm{T} 4$, whereas those grown with Cystoseira sp. only at T4. On the contrary, both Chaetomorpha sp. and, especially, Bioguano-grown plants reached shoot growth similar to the positive control throughout the trial.

Still focusing on leaves, Fig. 3 shows the leaf area of barley plants measured on a weekly basis. The Bioguano and the Chaetomorpha sp. treatments led to results comparable to the control and even higher, although not significantly. Chlorella $\mathrm{CH} 2$ treatment and the negative control confirm the already observed trend of a significant reduction compared to the positive control, whereas the Cystoseira sp. substrate showed no significant differences compared to the positive control, while its dry weight did (Fig. 2).

Figure 4 reports the roots dry weight observed at each sampling event.

Differently from the results obtained on the leaf system, the positive and the negative control showed no significant differences in root biomass production, with the negative control even higher at T4. Bioguano and Chaetomorpha sp. substrates led to similar responses compared to the positive control. On the contrary, with Chlorella $\mathrm{CH} 2$ and Cystoseira sp. root dry weight was significantly lower than in the positive control.

The shoot/root ratio of plants at the end of the trial is reported in Fig. 5. Only the negative control plants showed a significantly reduced shoot/root ratio compared to all the other treatments. On the opposite, Bioguano, Cystoseira sp., Chaetomorpha sp., and Chlorella $\mathrm{CH} 2$ resulted all comparable to the positive control, although a significant reduction was observed in the treatments with Chaetomorpha and Chlorella compared to Bioguano.

\section{Plant element uptake and nutrient use efficiency}

The element content in plant tissues at the end of the trial (T4) are reported in Table 3. While substrate addition in the system was set up to provide uniform conditions of $\mathrm{N}$ supply, $\mathrm{N}$ accumulation in plant tissues showed some differences among treatments, with nitrogen content of plants grown on Chlorella $\mathrm{CH} 2$, and to a much lesser extent, Cystoseira sp. and Bioguano, exceeding that of the positive control (Table 3).

Table 4 reports the total element uptake per system (22 plants). Comparing the results to the positive control, plants
Fig. 3 Barley leaf area $\left(\mathrm{mm}^{2}\right)$. Values are means \pm SEM (T1-T4, $n=4)$. Significant differences compared to the positive control $($ Control +$)$ are indicated as follows: $* P<0.05 ; * * P<0.01$; $* * * P<0.001$ (Tukey's test $P<$ $0.05)$

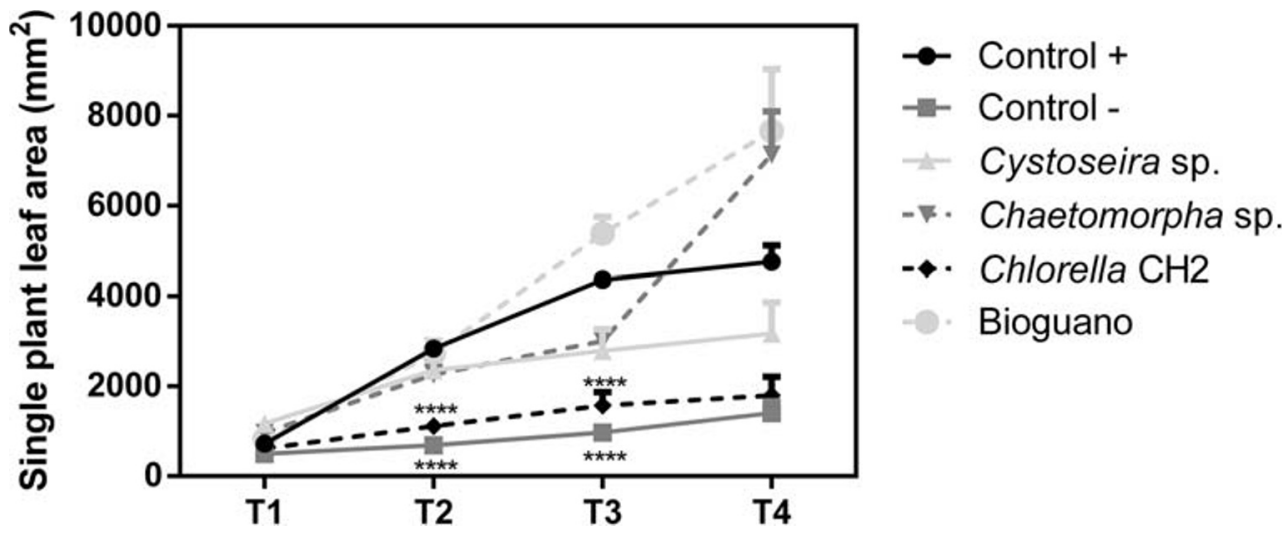


Fig. 4 Barley root performances expressed as average plant dry weight $(\mathrm{g})$. Values are means \pm SEM (T1, $n=4$; T2-T4, $n=6$ ). Significant differences compared to the positive control $(\mathrm{Control}+)$ are indicated as follows: $* P<$ $0.05 ; * * P<0.01 ; * * * P<0.001$ (Tukey's test, $P<0.05$ )

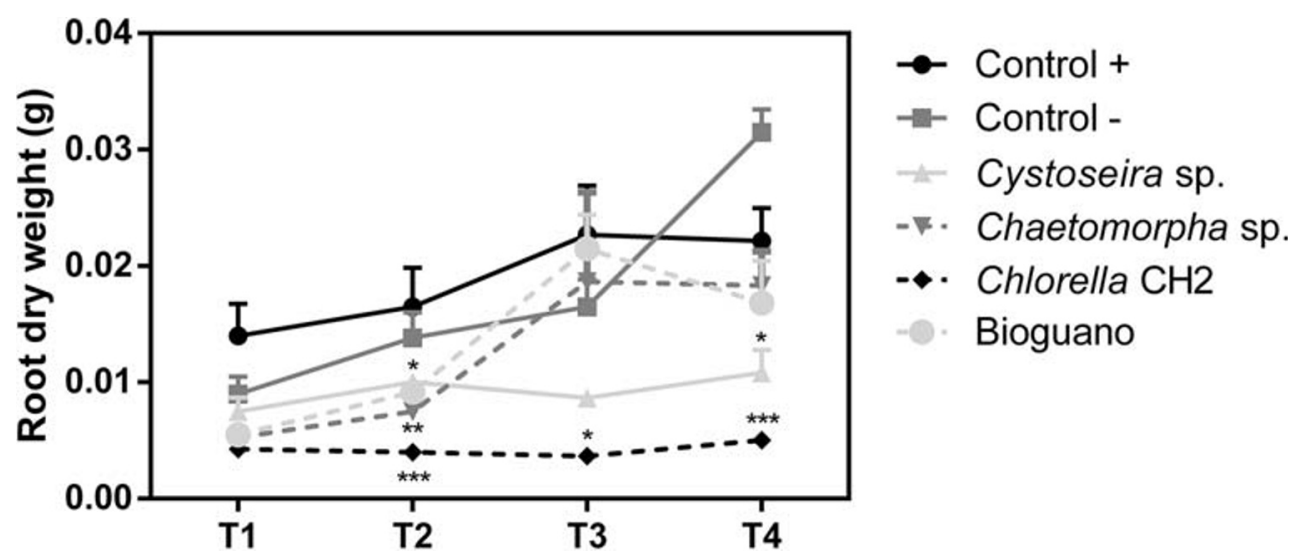

grown on Bioguano accumulated a similar $\mathrm{N}$ amount, whereas plants grown with the two macroalgae, an about 30\% lower amount. Bioguano-grown plants showed similar accumulation patterns compared to the positive control also for $\mathrm{P}$ and $\mathrm{Ca}$. On the contrary, plants grown on Chlorella $\mathrm{CH} 2$ took up remarkably lower amounts of each element compared to the positive control.

In Table 5, the elements uptake efficiency is reported. As already mentioned, substrate dosages were intended to provide uniform conditions in terms of $\mathrm{N}$ availability to plants. Nevertheless, results in $\mathrm{N}$ uptake efficiency (Table 5) revealed strong variations, with a minimum efficiency for Chlorella $\mathrm{CH} 2$-treated plants $(6.3 \%)$ and a maximum for the positive control $(81 \%)$. The plants on Bioguano reached a slightly lower efficiency in $\mathrm{N}$ uptake, and those grown on the two macroalgae showed intermediate values (21-32\%). None of

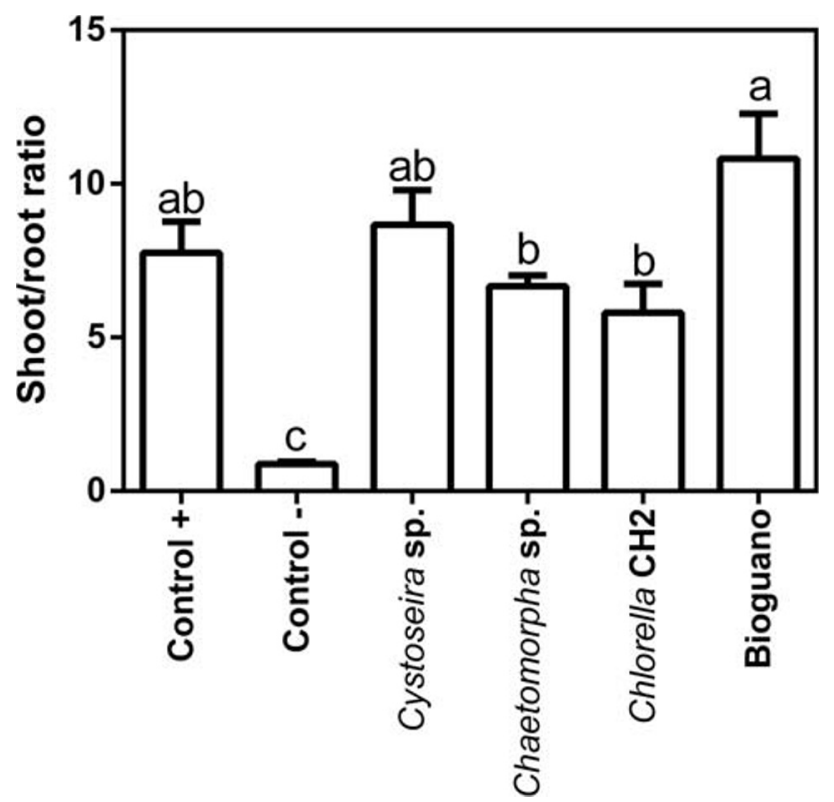

Fig. 5 Barley shoot/root ratio of plants collected at T4. Values are means $\pm \operatorname{SEM}(n=6)$. Different letters indicate a significant difference at $P<$ 0.05 (Tukey's test, $P<0.05$ ) the tested treatments achieved for the other elements, an uptake efficiency comparable to the positive control.

Figure 6 reports the nitrogen use efficiency (NUE) of the plants, calculated as the biomass produced per unit of $\mathrm{N}$ supplied with the different substrates. The results identify three main groups: the best NUE performing substrates, including Bioguano and the positive control; an intermediate group that includes the two macroalgae; a low performing group with Chlorella $\mathrm{CH} 2$-treated plants. Such results reflect the plants growth performances.

\section{Discussion}

\section{Plants growth}

Plants grown on Bioguano showed growth performances comparable to the positive control, while those on the macroalga Chaetomorpha sp. showed a lower, but not significantly different, growth. Plants on the macroalga Cystoseira sp. had a significantly lower biomass yield. On the other hand, Chlorella $\mathrm{CH} 2$ biomass showed to be an inadequate substrate for barley growth, with results comparable to the negative control. Our results suggest a high potential for Bioguano and, to a lesser extent, for macroalgae to be used as growing substrate for crops without any (Bioguano) or reduced (macroalgae) fertilizer supply. In particular, Bioguano and Chaetomorpha sp. showed the highest potential because of the highest plant biomass yield along with a good nutrient content in the plant biomass. In particular in Bioguanogrown plants, $\mathrm{P}, \mathrm{Fe}$, and $\mathrm{Mg}$ content was found to be higher than in the positive control, representing an interesting achievement of Bioguano substrate, as both iron and magnesium are important mineral elements lacking in the diet of a large proportion of the world's population (White and Broadley 2009). Supporters of organic agriculture generally claim that plants grown with synthetic fertilizers (and pesticides) have their natural defense system reduced: such loss can result in a limited content of minerals, vitamins, and many 
Table 3 Content of elements in plants (\% of dry weight). Values are means $\pm \operatorname{SEM}(n=3)$ of the analytical determination

\begin{tabular}{llllllll}
\hline & $\mathrm{N}$ & $\mathrm{P}$ & $\mathrm{K}$ & $\mathrm{Fe}$ & $\mathrm{Mg}$ & $\mathrm{Ca}$ \\
$\%$ & $\%$ & $\%$ & $\begin{array}{l}\mathrm{Na} \\
\%\end{array}$ & \\
\hline Control + & $5.10 \pm 0.04$ & $0.44 \pm 0.001$ & $5.79 \pm 0.05$ & $0.03 \pm 0.0001$ & $0.15 \pm 0.001$ & $0.34 \pm 0.002$ & $\mathrm{n} . \mathrm{a}$. \\
Control - & $1.47 \pm 0.01$ & $0.20 \pm 0.0002$ & $0.53 \pm 0.001$ & $0.004 \pm 0.00002$ & $0.17 \pm 0.0003$ & $0.54 \pm 0.001$ & $0.83 \pm 0.01$ \\
Cystoseira sp. & $5.70 \pm 0.09$ & $0.47 \pm 0.003$ & $3.02 \pm 0.01$ & $0.08 \pm 0.0003$ & $0.27 \pm 0.0003$ & $0.64 \pm 0.003$ & $1.02 \pm 0.01$ \\
Chaetomorpha sp. & $4.91 \pm 0.01$ & $0.30 \pm 0.005$ & $3.80 \pm 0.02$ & $0.04 \pm 0.0001$ & $0.17 \pm 0.001$ & $0.25 \pm 0.001$ & $0.48 \pm 0.004$ \\
Chlorella CH2 & $7.21 \pm 0.06$ & $0.38 \pm 0.001$ & $0.92 \pm 0.003$ & $0.01 \pm 0.00005$ & $0.15 \pm 0.0003$ & $0.08 \pm 0.0003$ & $0.36 \pm 0.002$ \\
Bioguano & $5.69 \pm 0.02$ & $0.62 \pm 0.002$ & $3.18 \pm 0.01$ & $0.14 \pm 0.001$ & $0.25 \pm 0.001$ & $0.29 \pm 0.002$ & $0.66 \pm 0.01$ \\
\hline
\end{tabular}

n.a., not available

defense-related metabolites that are considered beneficial traits in food (Brandt and Mølgaard 2001). Such an argumentation would explain our results in terms of mineral elements enrichment, even if we must acknowledge that, to date, with very few exceptions (e.g., vitamin $\mathrm{C}$ and nitrates), it has not been proven that organic fertilizers allow for more healthy and nutritious crops compared to conventional agriculture (Mie et al. 2017).

\section{Shoot and root biomass allocation provides insights on mineral elements balance}

Plants have a remarkable ability in coordinating the growth of above- and below-ground portions, with a tight balance between the biomass invested in shoots and roots (Poorter and Nagel 2000). According to Brouwer's theory of a "functional equilibrium," a plant shifts its allocation towards the portion facing the most limiting environment: shoots in limiting conditions of light and $\mathrm{CO}_{2}$, and roots at a low level of belowground resources, such as nutrients and water (Brouwer 1963). Poorter and Nagel (2000) proposed that such a shift in allocation could be seen as a plant adaptation, enabling the plant to capture more of those limiting resources. Besides, it is well established that allocation to roots increases with decreasing nutrient or water availability (Brenchley 1916), whereas allocation to shoots increases with decreasing irradiance

Table 4 Total element uptake amount per system

\begin{tabular}{llllllll}
\hline & $\begin{array}{l}\mathrm{N} \\
\mathrm{mg}\end{array}$ & $\begin{array}{l}\mathrm{P} \\
\mathrm{mg}\end{array}$ & $\begin{array}{l}\mathrm{K} \\
\mathrm{mg}\end{array}$ & $\begin{array}{l}\mathrm{Fe} \\
\mathrm{mg}\end{array}$ & $\begin{array}{l}\mathrm{Mg} \\
\mathrm{mg}\end{array}$ & $\begin{array}{l}\mathrm{Ca} \\
\mathrm{mg}\end{array}$ & $\begin{array}{l}\mathrm{Na} \\
\mathrm{mg}\end{array}$ \\
\hline Control + & 127.03 & 10.94 & 144.34 & 0.79 & 3.71 & 8.49 & n.a. \\
Control - & 13.43 & 1.85 & 4.82 & 0.03 & 1.55 & 4.91 & 7.62 \\
Cystoseira sp. & 94.41 & 7.72 & 49.97 & 1.40 & 4.55 & 10.68 & 16.81 \\
Chaetomorpha sp. & 85.32 & 5.18 & 66.10 & 0.75 & 3.00 & 4.32 & 8.34 \\
Chlorella $\mathrm{CH} 2$ & 63.88 & 3.40 & 8.14 & 0.11 & 1.37 & 0.70 & 3.17 \\
Bioguano & 139.48 & 15.09 & 78.05 & 3.35 & 6.24 & 7.16 & 16.25 \\
\hline
\end{tabular}

n.a., not available
(Shirley 1929). However, it is probably more appropriate to say that plants allocate biomass to different parts to reduce any imbalance between carbon fixation by leaves and nutrient acquisition by roots (Shipley and Meziane 2002). Therefore, implicit in this model is that a plant allocates its biomass in such a manner that its growth rate is maximal under the given environmental conditions (Poorter and Nagel 2000). Interestingly, among a number of investigated environmental variables, the effects of nutrients on biomass allocation were found to be the most remarkable, concluding that in the case of nutrients, biomass allocation is a major factor in the response of plants to a limited resources supply (Poorter and Nagel 2000). Such a theory still stands nowadays, with a recent study of Poorter et al. (2019) investigating the effect of daily light integral (DLI) on 70 traits related to plant anatomy, morphology, chemistry, physiology, growth, and reproduction and correlating the change in allocation of biomass with the higher requirements for water and nutrients by faster-growing and transpiring plants at high DLI. In fact, the hypothesis is that plants alter their physiology or morphology to maximize growth over their lifetime, and such a concept has been applied not only to biomass allocation but also to photosynthesis, stomatal conductance, and nutrient content (Caldararu et al. 2020).

As a consequence, the biomass allocation in shoot and root systems can provide information on the nutrient balance of the

Table 5 Element uptake efficiency (calculated by dividing the element absorbed by all plants at $\mathrm{T} 1+\mathrm{T} 2+\mathrm{T} 3+\mathrm{T} 4$ per system and the element given to the system through the treatment)

\begin{tabular}{llllllll}
\hline Treatment & $\mathrm{N}$ & $\mathrm{P}$ & $\mathrm{K}$ & $\begin{array}{l}\mathrm{Fe} \\
\%\end{array}$ & $\begin{array}{l}\mathrm{Mg} \\
\%\end{array}$ & $\begin{array}{l}\mathrm{Ca} \\
\%\end{array}$ & $\begin{array}{l}\mathrm{Na} \\
\%\end{array}$ \\
\hline Control + & 80.66 & 47.06 & 81.90 & 36.61 & 10.18 & 5.66 & n.a. \\
Cystoseira sp. & 31.67 & 28.47 & 13.94 & 2.05 & 6.59 & 4.12 & 7.09 \\
Chaetomorpha sp. & 21.09 & 27.53 & 12.19 & 2.01 & 4.88 & 1.91 & 3.72 \\
Chlorella $\mathrm{CH} 2$ & 6.29 & 2.42 & 6.93 & 0.77 & 2.34 & 1.19 & 2.17 \\
Bioguano & 60.38 & 6.91 & 41.03 & 5.24 & 7.94 & 1.33 & 8.42 \\
\hline
\end{tabular}

n.a., not available 


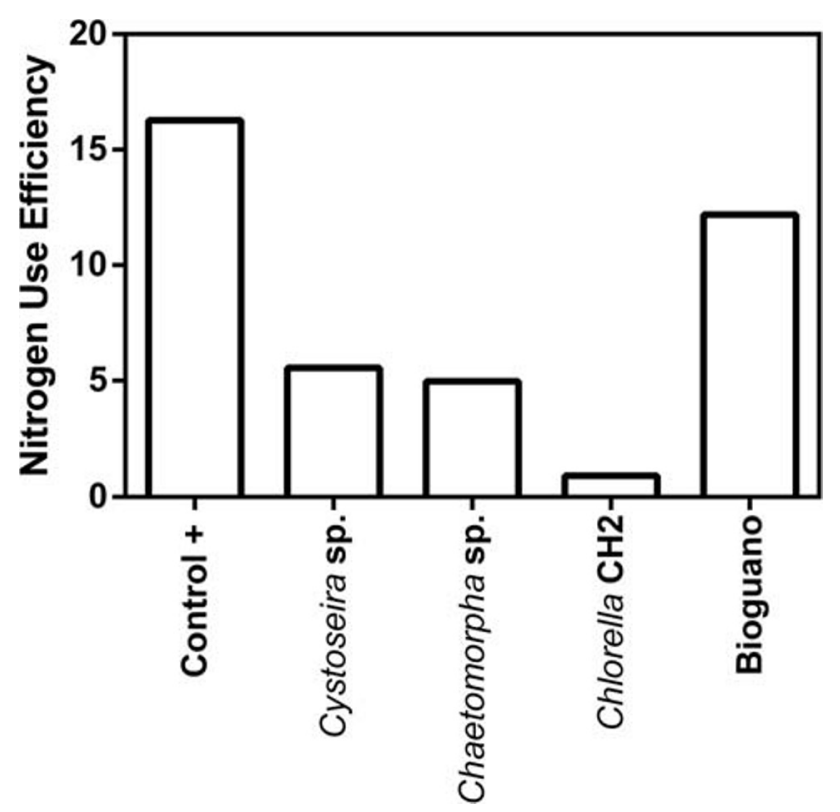

Fig. 6 Nitrogen use efficiency of barley plants produced per system

substrates used in the current experiment. In fact, since light and $\mathrm{CO}_{2}$ were the same for all treated plants, shoot and root biomass allocation can be used to evaluate possible mineral imbalances. The negative control faced nutrient deficiencies confirmed by the poor plant growth. On the other hand, the best performing substrates, Bioguano and Chaetomoprha, showed a root biomass reduction compared to the positive control, even if such reduction was not significant, whereas shoot performances were different with the two substrates although both not significantly different from the control; such result suggests that these substrates did not represent for barley plants mineral shortage conditions as, according to Brouwer's theory, the root biomass increases under mineral shortage conditions at the expense of the shoot (Brouwer 1963). The obtained shoot and root biomass results might indicate that the mineral elements supplied were adequate for plant growth. Such consideration was not guessable by observing Table 2. Besides, Bioguano substrate supplied a slightly increased $\mathrm{N}$ amount compared to the control, which translated into generally higher shoot performances and roots growth decrease. It was proved that shoot growth increases when the nitrogen supply is increased, and root growth decreases at the same time (Brouwer 1962). In accordance with Bioguano results, high nitrogen supply rate resulted in increased shoot/root ratio due to an increased shoot biomass yield with only small changes in root biomass yield (Brouwer 1962). Moreover, the shoot/root ratio of Chaetomorpha sp. (comparable to the positive control) seems to be justified by the above-described pattern of shootoriented allocation. Nevertheless, a high ratio was obtained also in Chlorella $\mathrm{CH} 2$-treated plants: reasons behind that seems anyhow different from Chaetomorpha sp. and Bioguano and are thus discussed in detail in the next paragraph. Cystoseira sp.-grown plants resulted in a shoot/ root ratio comparable to the positive control and Bioguano; the reason for this derives from a behavior intermediate between Chaetomorpha sp. and Chlorella $\mathrm{CH} 2$.

\section{Bad-performing plants suffered mineral elements deficit or toxicity?}

The reduced growth of the negative control compared to the positive control can be easily explained as a consequence of nutrient deficiency. In particular, the growth of the negative control shoots was more affected than roots. This is consistent with the results of a previous study where, while barley established on a very poor nutrient medium showed severe shoot biomass reduction, the effects on the root biomass were minor (Drew 1975). This situation is in accordance with Brouwer's theory.

The high shoot/root ratio of plants in the positive control, Bioguano and Chaetomorpha sp., on the other hand, can be explained considering the general increased shoot biomass together with a moderate root system, confirming as already said the theory of the sufficiency of nutrients provided with such treatments. By contrast, plants grown on Chlorella $\mathrm{CH} 2$, which also showed a quite high shoot/ root ratio, were characterized by a stunted epigeal apparatus, with its high ratio due to an even less developed root system, as limited as to suggest that some kind of toxicity occurred at the root level. This hypothesis might be supported by the results presented in Table 5, indicating that the elements uptake efficiency of plants treated with Chlorella $\mathrm{CH} 2$ is the lowest for any analyzed element compared to all other substrates. In a study conducted by Niccolai et al. (2017), the aqueous extract of Chlorella sorokiniana F\&M-M49 grown in F medium (a seawater-based medium), the same medium used for Chlorella $\mathrm{CH} 2$ in the present experiment, showed high toxicity to fibroblasts, while that of $C$. sorokiniana F\&M-M49 grown in BG11 medium (a fresh waterbased medium) exhibited no toxicity to fibroblasts, thus confirming that toxicity might depend on growth medium.

\section{Some treatments enhanced element accumulation in the plants}

Regarding plant elemental composition there is not a direct correlation between the amount supplied and the concentration in the plant, depending more on the specific uptake efficiency. The consistency between the amounts supplied and accumulated in the plant seemed stronger for specific treatments and depended very much from the element considered. For instance, the $\mathrm{N}$ amount supplied was similar for all the treatments, but Bioguano and Cystoseira sp. showed the highest $\mathrm{N}$ concentration in plants tissues. Concerning 
other elements, Chaetomorpha sp.-treated plants showed the lowest $\mathrm{P}$ accumulation in response to the lowest amount supplied and among the highest $\mathrm{K}$ accumulation following the highest amount supplied. Similarly, Cystoseira sp.treated plants showed among the highest $\mathrm{Fe}, \mathrm{Mg}, \mathrm{Ca}, \mathrm{Na}$ accumulation accordingly to the respective high amounts supplied.

The Bioguano substrate not only did show higher $\mathrm{N}$ uptake efficiency but also led to the highest $\mathrm{N}$ use efficiency, second only to the positive control. This aspect is particularly important because it allowed an early response in plants and a higher shoot/root ratio, as discussed above. Moreover, Bioguano enhanced the concentration of elements in plant tissues, i.e., $\mathrm{N}$, $\mathrm{P}, \mathrm{Fe}$, and $\mathrm{Mg}$ showing better performances compared to all the other tested treatments including the positive control. Since the diets of a large proportion of the world's population are deficient in $\mathrm{Fe}$ and $\mathrm{Mg}$ (White and Broadley 2009), this aspect should be further investigated in the edible-leaf crops, with the aim of enriching the endogenous nutrient concentration of food, thus achieving food biofortification (Ding et al. 2016), through organic fertilization made with macroalgae and guano mixtures. To reach such a goal several strategies are sought including the use of inorganic fertilizers (White and Broadley 2009), the improvement of crops mineral elements uptake (Lynch 2007), the exploitation of soil microorganisms to increase the volume of soil explored by crop plants (Rengel et al. 1999; Barea et al. 2005; Morgan et al. 2005; Lynch 2007), the use of inoculants of growth-promoting bacteria that can increase $\mathrm{Fe}, \mathrm{Zn}$, and $\mathrm{Cu}$ uptake by plant (Whiting et al. 2001; Barea et al. 2005), breeding crops with high mineral accumulation rates (White and Broadley 2009), using seawater as a complementary irrigation source (Atzori et al. 2016, 2017, 2019a, b, 2020; Caparrotta et al. 2019). The results of the current trial suggest that growing herbaceous species with macroalgae, cyanobacteria, and guano mixture fertilizer could enhance the accumulation of most elements in the biomass. In addition, calcium was found to significantly increase compared to control conditions in Cystoseira-treated barley. Being calcium one among the mineral elements that lacks in the diet of more than half of the world's population (White and Broadley 2009), it would be interesting to test a new mixture as Bioguano, but with Cystoseira sp. specifically among the macroalgae used.

The results on nutrient uptake efficiency support the feasibility of using some of the tested substrates as biofertilizers, in fact they show higher values than the estimates for soil fertilizers, assessed to be lower than $50 \%$ for N, $10 \%$ for P, and about $40 \%$ for K (Baligar et al. 2001). Anyhow in soilless cultivation nutrient efficiency estimates improve, even if strongly depending on the soilless system used (i.e., higher in closed-cycle hydroponics compared to open-cycle systems). However, to reach high uptake efficiency for all nutrients, a mixture of Bioguano and macroalgae is necessary. The general approach to face the low efficiencies has been to work on crops through the identification of traits that can enhance fertilizer use, with the aim of developing new cultivars characterized by higher nutrient use efficiency (Baligar et al. 2001). To assess the possibility of transferring the obtained results on soil fertilization, thus not only considering it for soilless cultivation fertigation, hydroponics has been assessed as a key experimental method for the evaluation of elements accumulation in plants (Cao et al. 2018), also taking advantage of the uniform exposure of the roots to the nutrient solution. Nevertheless, while for certain species and elements the correlation between their accumulation in hydroponics and in soil conditions have been proved (Watson et al. 2003), for barley such a correlation is still missing. Moreover, a study investigating barley salt tolerance in both hydroponics and soil conditions assessed differences in the obtained salt tolerance thresholds based, among other parameters, on differences in the concentration of ions (i.e., $\mathrm{Na}^{+}$and $\mathrm{K}^{+}$) (Tavakkoli et al. 2012); as a consequence, further investigations to experimentally confirm a possible transfer of the obtained results in soil-based conditions are still needed. Finally, our results suggest that it is worth to investigate a wide variety of biofertilizers, as the same crop gave very different results when treated with the different organic substrates.

\section{Conclusions}

In conclusion, this study highlights the high potential of Bioguano and macroalgae as substitutes of synthetic fertilizers. In particular, plants grown on Bioguano reached similar shoot weight compared to those grown on mineral fertilizer and attained rather high uptake efficiencies of $\mathrm{Mg}, \mathrm{N}$, and $\mathrm{K}$. Plants fertilized with macroalgae gave different results, and in one case barley plants grew similarly to plants on the mineral fertilizer while with both macroalgae plants showed high $\mathrm{P}$ uptake efficiency. The optimal biofertilizer emerging from this work would be a mixture of Bioguano and Chaetomorpha or Cystoseira.

Acknowledgments Open access funding provided by Università degli Studi di Firenze within the CRUI-CARE Agreement. We thank Sofia Pittera MSc for her skilled technical assistance in the preparation and characterization of the substrates and in the execution of the experiments.

\section{Compliance with ethical standards}

Conflict of interest The authors declare that they have no competing interests.

Open Access This article is licensed under a Creative Commons Attribution 4.0 International License, which permits use, sharing, adaptation, distribution and reproduction in any medium or format, as long as 
you give appropriate credit to the original author(s) and the source, provide a link to the Creative Commons licence, and indicate if changes were made. The images or other third party material in this article are included in the article's Creative Commons licence, unless indicated otherwise in a credit line to the material. If material is not included in the article's Creative Commons licence and your intended use is not permitted by statutory regulation or exceeds the permitted use, you will need to obtain permission directly from the copyright holder. To view a copy of this licence, visit http://creativecommons.org/licenses/by/4.0/.

\section{References}

Atzori G, Guidi Nissim W, Caparrotta S, Masi E, Azzarello E, Pandolfi C, Vignolini P, Gonnelli C, Mancuso S (2016) Potential and constraints of different seawater and freshwater blends as growing media for three vegetable crops. Agric Water Manag 176:255-262

Atzori G, de Vos AC, van Rijsselberghe M, Vignolini P, Rozema J, Mancuso S, van Bodegom PM (2017) Effects of increased seawater salinity irrigation on growth and quality of the edible halophyte Mesembryanthemum crystallinum L. under field conditions. Agric Water Manag 187:37-46

Atzori G, Guidi Nissim W, Caparrotta S, Santantoni F, Masi E (2019a) Seawater and water footprint in different cropping systems: a chicory (Cichorium intybus L.) case study. Agric Water Manag 211: 172-177

Atzori G, Mancuso S, Masi E (2019b) Seawater potential use in soilless culture: a review. Sci Hortic (Amsterdam) 249:199-207

Atzori G, Nissim WG, Macchiavelli T, Vita F, Azzarello E, Pandolfi C, Masi E, Mancuso S (2020) Tetragonia tetragonioides (Pallas) Kuntz. as promising salt-tolerant crop in a saline agricultural context. Agric Water Manag 240:240

Baligar VC, Fageria NK, He ZL (2001) Nutrient use efficiency in plants. Commun Soil Sci Plant Anal 32:921-950

Barber DA, Koonts HV (1963) Uptake of dinitrophenol \& its effect on transpiration \& calcium accumulation in barley seedlings. Plant Physiol 38:60-65

Barea JM, Pozo MJ, Azcón R, Azcón-Aguilar C (2005) Microbial cooperation in the rhizosphere. J Exp Bot 56:1761-1778

Brandt K, Mølgaard JP (2001) Organic agriculture: does it enhance or reduce the nutritional value of plant foods? J Sci Food Agric 81: 924-931

Brenchley WE (1916) The effect of the concentration of the nutrient solution on the growth of barley and wheat in water cultures. Ann Bot 30:77-90

Brouwer R (1962) Nutritive influences on the distribution of dry matter in the plant. Neth J Agric Sci 10:399-408

Brouwer R (1963) Some aspects of the equilibrium between overground and underground plant parts. Jaarb van het Inst voor Biol en Scheikd Onderz van Landbouwgewassen 94:31-39

Caldararu S, Thum T, Yu L, Zaehle S (2020) Whole-plant optimality predicts changes in leaf nitrogen under variable $\mathrm{CO}_{2}$ and nutrient availability. New Phytol 225:2331-2346

Calicioglu O, Flammini A, Bracco S, Bellù L, Sims R (2019) The future challenges of food and agriculture: an integrated analysis of trends and solutions. Sustainability 11:su11010222

Cao Y, Zhang Y, Ma C, Li H, Zhang J, Chen G (2018) Growth, physiological responses, and copper accumulation in seven willow species exposed to $\mathrm{Cu}-\mathrm{a}$ hydroponic experiment. Environ Sci Pollut Res 25:19875-19886

Caparrotta S, Masi E, Atzori G, Diamanti I, Azzarello E, Mancuso S, Pandolfi C (2019) Growing spinach (Spinacia oleracea) with different seawater concentrations: effects on fresh, boiled and steamed leaves. Sci Hortic (Amsterdam) 256:1-7

Chanda M, Benhima R, Elmernissi N, Kasmi Y, Lyamlouli K, Sbabou L, Zeroual Y, El Arroussi H (2020) Screening of microalgae liquid extracts for their bio stimulant properties on plant growth, nutrient uptake and metabolite profile of Solanum lycopersicum L. Sci Rep 10

Chaudhari S, Patra A, Biswas D (2018) Soil and water management innovations towards doubling the farmers 'income. Bull Indian Soc Soil Sci 32:1-110

Craigie JS (2011) Seaweed extract stimuli in plant science and agriculture. J Appl Phycol 23:371-393

Delogu G, Cattivelli L, Pecchioni N, De Falcis D, Maggiore T, Stanca AM (1998) Uptake and agronomic efficiency of nitrogen in winter barley and winter wheat. Eur J Agron 9:11-20

Ding J, Yang T, Feng H, Dong M, Slavin M, Xiong S, Zhao S (2016) Enhancing contents of $\gamma$ - aminobutyric acid (GABA) and other micronutrients in dehulled rice during germination under normoxic and hypoxic conditions. J Agric Food Chem 64:1094-1102

Drew MC (1975) Comparison of the effects of a localized supply of phospate, nitrate, ammonium and potassium on the growth of the seminal root system, and the shoot, in barley. New Phytol 75:479 490

du Jardin P (2015) Plant biostimulants: definition, concept, main categories and regulation. Sci Hortic (Amsterdam) 196:3-14

EPA (1996) Method 3052: microwave assisted acid digestion of siliceous and organically based matrices. Test Method, Washington, DC

FAO (2006) Plant nutrition for food security- a guide for intergrated nutrient management. The Food and Agriculture Organization of the United Nations, Rome

FAO (2016) The state of food and agriculture, climate change, agriculture and food security. The Food and Agriculture Organization of the United Nations, Rome

FAO (2017) The future of food and agriculture trends and challenges. The Food and Agriculture Organization of the United Nations, Rome

Foley JA, DeFries R, Asner GP, Barford C, Bonan G, Carpenter SR, Chapin FS, Coe MT, Daily GC, Gibbs HK, Helkowski JH, Holloway T, Howard EA, Kucharik CJ, Monfreda C, Patz JA, Prentice IC, Ramankutty N, Snyder PK (2005) Global consequences of land use. Science 309:570-574

Garcia-Gonzalez J, Sommerfeld M (2016) Biofertilizer and biostimulant properties of the microalga Acutodesmus dimorphus. J Appl Phycol 28:1051-1061

Guidi Nissim W, Palm E, Mancuso S, Azzarello E (2019) Trace element partitioning in a poplar phytoextraction stand in relation to stem size. J Environ Manag 247:688-697

Guillard RRL, Ryther JH (1962) Studies of marine planktonic diatoms: I. Cyclotella nana Hustedt, and Detonula confervacea (Cleve) Gran. Can J Microbiol 8:229-239

He Q, Wang X, He L, Yang L, Wang S, Bi Y (2019) Alternative respiration pathway is involved in the response of highland barley to salt stress. Plant Cell Rep 38:295-309

Hoagland DR (1938) The water-culture method for growing plants without soil. Univ Calif Coll Agric Agric Exp Stn Circ 3

Hurtado AQ, Critchley AT (2018) A review of multiple biostimulant and bioeffector benefits of AMPEP, an extract of the brown alga Ascophyllum nodosum, as applied to the enhanced cultivation and micropropagation of the commercially important red algal carrageenophyte Kappaphycus alvarezii. J Appl Phycol 30:28592873

ISO (2016) Food products - Determination of the total nitrogen content by combustion according to the Dumas principle and calculation of the crude protein content - Part 2: cereals, pulses and milled cereal products. ISO16634.2:2016

Khan W, Rayirath UP, Subramanian S, Jithesh MN, Rayorath P, Hodges DM, Critchley AT, Craigie JS, Norrie J, Prithiviraj B (2009) 
Seaweed extracts as biostimulants of plant growth and development. J Plant Growth Regul 28(4):386-399

Kim MJ, Shim CK, Kim YK, Ko BG, Park JH, Hwang SG, Kim BH (2018) Effect of biostimulator Chlorella fusca on improving growth and qualities of chinese chives and spinach in organic farm. Plant Pathol J 34:567-574

Krotz L, Leone F, Giazzi G (2016) Nitrogen/protein determination in food and animal feed by combustion method (Dumas) using the Thermo Scientific FlashSmart Elemental Analyzer. Thermo Fisher Application Note AN42262-EN 0716

Le Gouis J, Béghin D, Heumez E, Pluchard P (2000) Genetic differences for nitrogen uptake and nitrogen utilisation efficiencies in winter wheat. Eur J Agron 12:163-173

Lötze E, Hoffman EW (2016) Nutrient composition and content of various biological active compounds of three South African-based commercial seaweed biostimulants. J Appl Phycol 28:1379-1386

Lynch JP (2007) Roots of the second Green Revolution. Aust J Bot 55: 493-512

Mie A, Andersen HR, Gunnarsson S, Kahl J, Kesse-Guyot E, Rembialkowska E, Quaglio G, Grandjean P (2017) Human health implications of organic food and organic agriculture: a comprehensive review. Environ Health 16:1-22

Morgan JAW, Bending GD, White PJ (2005) Biological costs and benefits to plant-microbe interactions in the rhizosphere. J Exp Bot 56: 1729-1739

Niccolai A, Bigagli E, Biondi N, Rodolfi L, Cinci L, Luceri C, Tredici MR (2017) In vitro toxicity of microalgal and cyanobacterial strains of interest as food source. J Appl Phycol 29:199-209

Poorter H, Nagel O (2000) The role of biomass allocation in the growth response of plants to different levels of light, $\mathrm{CO}_{2}$, nutrients and water: a quantitative review. Aust J Plant Physiol 27:595-607

Poorter H, Niinemets Ü, Ntagkas N, Siebenkäs A, Mäenpää M, Matsubara S, Pons TL (2019) A meta-analysis of plant responses to light intensity for 70 traits ranging from molecules to whole plant performance. New Phytol 223:1073-1105

Pradhan P, Fischer G, van Velthuizen H, Reusser DE, Kropp JP (2015) Closing yield gaps: how sustainable can we be? PLoS One 10: e0129487

Puglisi I, Barone V, Fragalà F, Stevanato P, Baglieri A, Vitale A (2020) Effect of microalgal extracts from Chlorella vulgaris and Scenedesmus quadricauda on germination of Beta vulgaris seeds. Plants 9

Ramankutty N, Mehrabi Z, Waha K, Jarvis L, Kremen C, Herrero M, Rieseberg LH (2018) Trends in global agricultural land use: implications for environmental health and food security. Annu Rev Plant Biol 69:789-815

Rengel Z, Batten GD, Crowley DE (1999) Agronomic approaches for improving the micronutrient density in edible portions of field crops. Food Crop Res 60:27-40

Salvi L, Brunetti C, Cataldo E, Niccolai A, Centritto M, Ferrini F, Mattii GB (2019) Effects of Ascophyllum nodosum extract on Vitis vinifera: Consequences on plant physiology, grape quality and secondary metabolism. Plant Physiol Biochem 139:21-32
Sayed SM, Abd El-Dayem HM, El-Desouky SA, Khedr ZM, Samy MM (2018) Effect of silicon and algae extract foliar application on growth and early yield of globe artichoke plants. Ann Ag Sci Moshtohor 56:207-214

Senesi N (1989) Composted materials as organic fertilizers. Sci Total Environ 81-82:521-542

Shaaban MM (2001) Nutritional status and growth of maize plants as affected by green microalgae as soil additives. Online J Biol Sci 1: 475-479

Shipley B, Meziane D (2002) The balanced-growth hypothesis and the allometry of leaf and root biomass allocation. Funct Ecol 16:326331

Shirley HL (1929) The influence of light intensity and light quality upon the growth of plants. Am J Bot 16:354-390

Stirk WA, Rengasamy KRR, Kulkarni MG, van Staden J (2020) Plant biostimulants from seaweed: an Overview. In: Geelan D, Xu L (eds) The chemical biology of plant biostimulants. Wiley, Chichester, pp $33-55$

Tavakkoli E, Fatehi F, Rengasamy P, McDonald GK (2012) A comparison of hydroponic and soil-based screening methods to identify salt tolerance in the field in barley. J Exp Bot 63:3853-3867

Tilman D, Cassman KG, Matson PA, Naylor R, Polasky S (2002) Agricultural sustainability and intensive production practices. Nature 418:671-677

Tredici MR (2010) Photobiology of microalgae mass cultures: understanding the tools for the next green revolution. Biofuels 1:143-162

Tredici MR, Rodolfi L, Biondi N, Bassi N, Sampietro G (2016) Technoeconomic analysis of microalgal biomass production in a 1-ha Green Wall Panel (GWP ®) plant. Algal Res 19:253-263

Watson C, Pulford ID, Riddell-Black D (2003) Screening of willow species for resistance to heavy metals: comparison of performance in a hydroponics system and field trials. Int J Phytoremediation 5:351365

White PJ, Broadley MR (2009) Biofortification of crops with seven mineral elements often lacking in human diets-iron, zinc, copper, calcium, magnesium, selenium and iodine. New Phytol 182:49-84

Whiting SN, De Souza MP, Terry N (2001) Rhizosphere bacteria mobilize $\mathrm{Zn}$ for hyperaccumulation by Thlaspi caerulescens. Environ Sci Technol 35:3144-3150

Win TT, Barone GD, Secundo F, Fu P (2018) Algal biofertilizers and plant growth stimulants for sustainable agriculture. Ind Biotechnol 14:203-211

Zhao C, Wang X, Wang X, Wu K, Li P, Chang N, Wang J, Wang F, Li J, Bi Y (2015) Glucose-6-phosphate dehydrogenase and alternative oxidase are involved in the cross tolerance of highland barley to salt stress and UV-B radiation. J Plant Physiol 181:83-95

Zodape ST (2001) Seaweeds as a biofertilizer. J Sci Ind Res (India) 60: 378-382

Publisher's note Springer Nature remains neutral with regard to jurisdictional claims in published maps and institutional affiliations. 